University of Rhode Island

DigitalCommons@URI

2018

In the Battle Against Inequality, States Take the Lead

Ping Xu

University of Rhode Island, pingxu@uri.edu

Follow this and additional works at: https://digitalcommons.uri.edu/psc_facpubs

The University of Rhode Island Faculty have made this article openly available.

Please let us know how Open Access to this research benefits you.

This is a pre-publication author manuscript of the final, published article.

Terms of Use

This article is made available under the terms and conditions applicable towards Open Access

Policy Articles, as set forth in our Terms of Use.

Citation/Publisher Attribution

Ping Xu; In the Battle Against Inequality, States Take the Lead, Journal of Public Administration Research and Theory, Volume 28, Issue 3, 15 June 2018, Pages 442-444, https://doi.org/10.1093/jopart/muy015 Available at: https://doi.org/10.1093/jopart/muy015

This Book Review is brought to you for free and open access by the Political Science at DigitalCommons@URI. It has been accepted for inclusion in Political Science Faculty Publications by an authorized administrator of DigitalCommons@URI.For more information, please contact digitalcommons-group@uri.edu. 


\section{In the Battle Against Inequality, States Take the Lead}

William Franko and Christopher Witko. 2017. The New Populism: How States Respond to Economic Inequality. New York: Oxford University Press. 230 pp. \$34.95 (Hardcover)

William Franko and Christoper Witko's new text titled The New Economic Populism: How States Respond to Economic Inequality is a timely book on rising income inequality in the US. The authors deliver a promising message to those who are concerned about inequality: despite the federal government's inaction, American states begin to combat rising inequality and such state actions are linked to the growing public awareness of rising inequality. The authors do an excellent job introducing the centerpiece of their theoretical argument— "the new economic populism." They successfully link state policies used to combat inequality (i.e., Earned Income Tax Credit (EITC), raising taxes on the wealthy, and raising the minimum wage) with mounting public awareness of inequality among the general population. The theoretical arguments of the book are logical, and the empirical evidence is convincing. This book makes an important contribution to the field of American political economy, and it adds an invaluable asset to the existing income inequality literature.

The authors open the book with sweeping evidence of the ever-growing income inequality in the US during the past three decades. They discuss the dire effects that rising inequality has brought to society and politics and argue that, in face of drastic and persistent increases in inequality, the federal government took little action to solve the problem. In contrast, it adopted multiple policies benefiting corporations and their managers with higher profits and wages. For example, the federal government cut taxes for the wealthy, deregulated the financial sector, and bailed out the financial market after a major financial crisis. Unions and collective bargaining power instead declined substantially since the Reagan years.

Considering the federal government's inaction on combating inequality, the authors turn their attention to the actions of state governments. They discover that states, "are beginning to meaningfully address growing economic inequality through a variety of means, depending on specific state economic, political, and institutional conditions" (p. 11). For example, "many states are taking steps to combat inequality, from increasing minimum wages, to raising taxes on the wealthy and expanding tax credits for low-income workers" (p. 11). The authors call this trend the "new economic populism" because such state governmental reactions are based on growing public awareness of the inequality problem.

The authors are wise to introduce public opinion into the study of state policies on inequality, and they deliver a convincing causal story on how new economic populism drives states to combat inequality. To begin, the authors examine public awareness of rising income inequality in Chapter 3 and find that public awareness of inequality is heavily influenced by objective inequality levels on the state-level. More specifically, both top income shares and poverty rates at the state level significantly shape perceptions of inequality. Other factors such as mass partisanship at the state level also influence public perception of inequality, meaning states with more Democratic residents perceive more inequality. 
When the public becomes more aware of the inequality problem, they will find ways to voice their opinion. The recent Occupy Movement is a primary example. In Chapter 4, the authors argue that in states where there is greater awareness of inequality, the public will be more likely to elect politicians who will advance the economic interests of the lower and middle classes, and that strategic politicians will take advantage of the lack of federal action to try to reduce inequality. This causal mechanism is consistent with the textbook theories of democracy, but testing the mechanism itself is a difficult task. Instead, the authors provide strong evidence for the connection between public awareness of inequality and state government liberalism. In Chapter 4, they show that greater public perception of inequality is linked to more liberal state governments, and more liberal state governments are linked to lower inequality. In other words, public perceptions of inequality motivate state governments to be more left-leaning, and left-leaning state governments are more likely to address the inequality problem.

In Chapters 5 through 7, the authors provide additional evidence on the connection between growing public awareness of inequality and state-level actions to reduce inequality. In Chapter 5, the authors use the state of Washington's highly redistributive Initiative 1098 as an example to examine how public perceptions of inequality influence the formation of tax policy preferences at the individual level. By using data collected from a telephone-based survey, they find that voters who were more aware of income inequality were more supportive of this tax increase on the wealthy.

Besides levying more taxes on the rich, states could consider an Earned Income Tax Credit (EITC) or increasing the minimum wage. In Chapter 6, the authors examine the determinants of state minimum wages. They find that public awareness of growing inequality is a strong predictor of increases in state minimum wages. In addition, liberal state governments are more likely to raise state minimum wages as liberal governments often represent the lower income groups. In Chapter 7, the authors examine the determinants of state adoptions of EITC. They find that the growing awareness of inequality, again, will make states more likely to adopt EITC. In other words, EITC, equivalent to tax cuts to the poor, expand substantially at the state level as the public becomes more aware of income inequality problems.

Together, Chapters 4-7 deliver a promising message: the growing public awareness of inequality is not only associated with state government liberalism but also shapes state policies. As the public becomes more aware of inequality, state governments are more likely to be left-leaning and also more likely to adopt egalitarian policies to combat income disparities. Overall, this book examines a very timely and important question. Its biggest contribution, in my opinion, is to successfully link public opinion with state policies that address widening income disparities. Theoretically, the authors tell a logical and convincing causal story of how populism (i.e. public perceptions of inequality) affects policy-making across different policy spectrums at the state level. Methodologically, they did an excellent job by providing solid evidence for their arguments.

A few constructive comments can be offered on this well-done book project. My first critique is about the federal government's role in combating inequality. Although the authors are very optimistic that the new economic populism will eventually prompt the federal government to take 
actions to combat inequality, their book primarily focuses on state government actions. The ultimate solution for inequality still lies with the federal government where there are greater resources and larger capacity for redistribution. Therefore, state actions to combat inequality are necessary but insufficient.

Yet, as the authors state, it is understandable for the federal government not to tackle inequality because of at least two reasons: (1) with numerous veto points in the system, the federal government was intentionally designed not to do much other than maintain the status quo and (2) the wealthy beneficiaries of growing inequality are very good at lobbying politicians at the federal level for policies that would continue to be self-serving. Given this, should we expect a different federal response on inequality in the future? Furthermore, given that the federal government did not respond to fierce public outcry like the Occupy Movement or to a devastating financial crisis, why should we expect it to change its actions? I think readers like myself would really like to be convinced that the impact of this new economic populism will go beyond the states and also work at the federal level, but we struggle to make the connection here. With the new Trump administration further cutting taxes for the wealthy, rolling back on the social safety net, and encouraging deregulation for businesses, the doubts deepen even more. Perhaps the authors could provide more discussion of how and why populism would eventually affect federal government actions.

I am also curious whether certain environments will help or inhibit public perceptions of inequality to influence state actions. A perpetual dilemma for modern governments is the choice between efficiency and equality, especially given pressures from globalization. For example, stagnant wages for low-income American workers is an important contributing factor of rising inequality. Previous research shows that the deepening of globalization, especially free trade with low-wage developing countries, contributed to declining wages for manufacturing workers in the US (Autor et al., 2013). Under this pressure, it is ultimately the government's decision whether or not to choose efficiency over equality and whether or not to choose corporations' benefits over the interest of American working class. It is anything but an easy choice. On the one hand, the governments need to cut taxes for corporations and create friendly environments in order to attract international firms and avoid capital flight in an increasingly globalized environment. On the other hand, they need to make sure vulnerable citizens who suffer from globalization are well taken care of.

For a book project that exclusively examines governments' reactions to inequality, my suggestion is that perhaps the authors can put more thought into the dilemma the government faces between the globalization pressure for more efficiency and the domestic pressure for more equality. On the empirical side, I think public awareness of inequality is likely to have a stronger impact on policymaking in some environments compare to others. For example, in states that are exposed to little global competition, public perception of inequality may have a stronger effect on egalitarian policies. In states exposed to high global competition, public perception of inequality may not have as big an effect on state actions. Additionally, I think public perception of income inequality may have an interactive effect with state government ideology. In other words, states with both a liberal state 
government and high levels of inequality perceptions should see the most egalitarian policies being made. Of course these are merely theoretical speculations, and it would be nice to see them tested.

Last but not the least, the authors focus on public perceptions of income inequality in their book, which is different from concerns of inequality. The public being aware of the inequality problem does not necessarily mean that they are also worried or concerned about it. The authors are aware of such a difference, but still used the words "perceptions" of inequality and "concerns" about inequality interchangeably throughout the book.

This book has a lot of strong points and is well worth a good read by individuals from in and outside of academia. If the authors could offer more discussions and evidence on the broader implications of such economic populism and embed such discussions in the context of increased globalization, it will immensely enhance the impact of the book.

\section{References:}

Autor, David H., David Dorn, and Gordon H. Hanson. 2013. "The China Syndrome: Local Labor Market Effects of Import Competition in the United States." American Economic Review 103(6):212168 